\title{
ANALISIS KONSENTRASI KLOR AKTIF PADA SALURAN DISTRIBUSI AIR PDAM KABUPATEN BULELENG
}

\author{
I Wayan Adiputra Gunawan \\ Universitas Pendidikan Ganesha \\ Singaraja, Indonesia \\ e-mail: adiputragnw@gmail.com
}

\begin{abstract}
Abstrak
Penelitian ini bertujuan untuk mengetahui mengetahui kualitas air minum PDAM Kabupaten Buleleng ditinjau dari konsentrasi klor aktif pada saluran distribusi. Penelitian ini dilakukan pada saluran distribusi air PDAM Kabupaten Buleleng yang didistribusikan dari reservoir Tegal Sari. Subjek penelitian ini adalah air minum PDAM Kabupaten Buleleng. Objek penelitian ini adalah konsentrasi klor aktif pada air minum PDAM Kabupaten Buleleng. Data yang diperoleh dalam penelitian ini adalah data konsentrasi klor aktif yang dianalisis secara deskriptif. Hasil penelitian menunjukkan (1) konsentrasi klor aktif rata-rata pada saluran distribusi air minum PDAM Kabupaten Buleleng adalah antara 0,11-0,4 mg/L. Air minum PDAM Kabupaten Buleleng pada saluran distribusi ini memiliki kualitas yang baik bila ditinjau dari konsentrasi klor aktif karena memenuhi syarat kualitas air minum dari Departemen Kesehatan (Depkes) dalam PERMENKES No.907/MENKES/VII/2002. (2) konsentrasi klor aktif mengalami penurunan seiring dengan bertambahnya j arak distribusi. Konsentrasi klor aktif pada sore hari lebih kecil dari konsentrasi klor aktif pada pagi dan siang hari.
\end{abstract}

Kata kunci: Analisis, Konsentrasi, Klor Aktif, Reservoir, Saluran Distribusi

\begin{abstract}
This study aimed to determine the quality of water in Buleleng PDAM Buleleng in terms of the active chlorine concentration in the distribution channel. This research was conducted on the air distribution channel of PDAM Buleleng which was diverted from the Tegal Sari reservoir. The subject of this research is PDAM Buleleng water. The object of this research is the active chlorine concentration in PDAM Buleleng water. The data obtained in this study were active chlorine deposition data which were analyzed descriptively. The results showed (1) the average concentration of active chlorine in the distribution of the of PDAM Buleleng water channels was between 0.11-0.4 mg / L. PDAM Buleleng in this distribution channel was of good quality when viewed from the concentration. active chlorine because it meets the drinking water quality requirements of the Departemen Kesehatan (Depkes) in PERMENKES No.907 / MENKES / VII / 2002. (2) the concentration of active chlorine has decreased along with the increase in the distribution of arak. The active chlorine concentration is smaller than the active chlorine concentration in the morning.
\end{abstract}

Keywords: Analysis, Concentration, Active Chlorine, Reservoir, Distribution Channel

\section{Pendahuluan}

Air sangat penting untuk kehidupan, tidak satupun kehidupan yang ada di dunia ini dapat berlangsung terus tanpa tersedianya air yang cukup. Bagi manusia kebutuhan akan air sangat mutlak, karena sebenarnya zat pembentuk tubuh manusia sebagian besar terdiri dari air, yang jumlahnya sekitar $73 \%$. Selain itu dalam setiap aktivitasnya, manusia selalu menggunakan air; baik untuk keperluan minum, kebutuhan rumah tangga, perkebunan, perikanan dan aktivitas lainnya (Totok Sutrisno dalam Sudiana, 2002).

Mengingat bahwa tidak ada air yang $100 \%$ mumi dalam arti yang sesuai dengan syarat air yang patut untuk kesehatan, maka harus juga diusahakan air yang ada sedemikian rupa sehingga syarat yang dibutuhkan terpenuhi. Berdasarkan kenyataan tersebut maka dilakukan beberapa pengolahan air agar menjadi air yang dapat dikonsumsi sesuai dengan kebutuhan, 
seperti air minum, memasak, mencuci dan kegiatan rumah tangga lainnya, perkebunan, dan perikanan. Dalam penyediaan air bersih bagi masyarakat kota Singaraja maka PDAM Kabupaten Buleleng melakukan upaya pengolahan dengan proses disinfeksi dengan menggunakan gas klor. Disinfeksi ini dilakukan pada jaringan pipa ketika air akan masuk ke Reservoir. Gas klor dipakai sebagai disinfektan karena harganya murah dan masih mempunyai daya desinfeksi sampai beberapa lama setelah pembubuhan. Selain itu apabila menggunakan gas klor maka proses disinfeksi dapat dilakukan dengan lebih efisien dan praktis karena dapat dilakukan dengan menggunakan alat injektor. Di dalam saluran distribusi jumlah klor aktif maksimum yang diperbolehkan ada adalah sebesar $5 \mathrm{mg} / \mathrm{L}$ (PERMENKES No.907/MENKES/SK/VII/2002 dan G Alaerts ). Pengukuran konsentrasi klor aktif di dalam saluran distribusi air dapat dilakukan dengan metode kolorimetri. Kolorimetri adalah pengukuran serapan cahaya tampak oleh suatu senyawa (Winaja, 1986).

Kebutuhan masyarakat akan air khususnya di Kabupaten Buleleng terus mengalami peningkatan. PDAM Kabupaten Buleleng sebagai suatu perusahaan daerah yang bergerak dalam penyediaan air minum di Kabupaten Buleleng, terus berupaya melakukan pengembangan penyediaan air minum bagi masyarakat Kabupaten Buleleng. Upaya yang dilakukan antara lain dengan terus mencari sumber- sumber air untuk memenuhi kebutuhan air masyarakat Buleleng. Sumber-sumber mata air yang dimiliki berasal dari mata air alami dan mata air buatan seperti; sumur bor. Jumlah sumber mata air yang dimiliki oleh PDAM Kabupaten Buleleng sebanyak 25 yang diantaranya 14 sumber mata air alami, dan 11 sumur bor yang tersebar pada beberapa tempat di Kabupaten Buleleng, seperti; di bagian kota ada sumber mata air Mumbul, di Kecamatan Sukasada ada sumber mata air Panca Sari, di kecamatan Kubutambahan ada mata Air Sanih, dan beberapa sumur bor di kawasan Penarukan. Dalam proses penyediaan air minum di kota Singaraja maka air yang diambil dari sumber mata air Mumbul yang berada di daerah lebih rendah dipompakan terlebih dahulu ke suatu reservoir yang berlokasi di tempat yang lebih tinggi. Adapun beberapa reservoir yang dipergunakan dalam pelayanaan air minum bagi masyarakat kota Singaraja antara lain reservoir Giri Putri, reservoir Bantang Banua, dan reservoir Tegal Sari.

Kondisi sumber mata air mumbul yang digunakan dalam pelayanan air minum PDAM Kabupaten Buleleng ini memiliki kualitas yang baik, hal ini dapat dilihat dari hasil pemeriksaan air yang dilakukan oleh bagian laboratorium pengawasan kualitas air PDAM Kabupaten Buleleng yang dilakukan secara rutin belum pernah ada parameter yang melampaui nilai ambang batas (batas konsentrasi maksimum) baik parameter fisika, kimia, maupun mikrobiologi seperti yang tercantum dalam PERMENKES No.907/MENKES/SK/VII/2002, sehingga pengolahan yang dilakukan hanya dengan melakukan proses disinfeksi. Disinfeksi yang dilakukan adalah dengan menggunakan gas klor (Ch). Proses disinfeksi dilakukan ketika air masuk ke reservoir dengan menginjeksikan gas klor melaui injektor pada jaringan pipa. Proses disinfeksi yang dilakukan merujuk pada pedoman laboratorium pengawasan air dari menteri kesehatan. Proses desinfeksi yang dilakukan bertujuan untuk membunuh mikroorganisme yang ada dalam air yang membahayakan kesehatan manusia.

Salah satu hal yang harus dipertimbangkan dalam proses disinfeksi menggunakan gas klor adalah konsentrasi disinfektan selama proses distribusi sampai ke konsumen. Hilangnya disinfektan sepanjang saluran distribusi menyebabkan teijadinya penurunan jumlah disinfektan selama pendistribusian, hal ini terjadi karena adanya proses absorpsi zat disinfektan oleh mikroorganisme dalam hal ini bakteri patogen (Winaja,1986), reduksi oleh logam-logam yang ada dalam air, serta terjadinya proses penguapan gas klor di sepanjang saluran distribusi. Pemeriksaan konsentrasi klor aktif dalam jaringan distribusi ( konsumen ) penting untuk dilakukan karena dengan mengetahui konsentrasi klor aktif yang tersisa pada jaringan distribusi akan dapat diketahui apakah jumlah klor aktif yang ada tersebut masih memenuhi standar PERMENKES No.907/MENKES/SK/VII/2002 sehingga tidak berdampak buruk bagi kesehatan masyarakat. Selain itu dengan melakukan analisis terhadap klor aktif pada saluran distribusi PDAM ( konsumen ) akan dapat diketahui jumlah klor aktif yang hilang selama pendistribusian air. Dalam jaringan distribusi ( konsumen ) sisa klor aktif maksimum yang diperbolehkan adalah sebesar $5 \mathrm{mg} / \mathrm{L}$ (PERMENKES No.907/MENKES/SK/VII/2002). Konsentrasi klor yang dibubuhkan di reservoir harus dipertimbangkan dengan cermat agar klor aktif yang ada dalam jaringan distribusi tidak melampaui ambang batas ( lebih dari $5 \mathrm{mg} / \mathrm{L}$ ). Jika konsentasi klor aktif yang ada dalam jaringan distribusi lebih besar dari $5 \mathrm{mg} / \mathrm{L}$ dapat berdampak buruk bagi kesehatan masyarakat karena klor bersifat racun dan menimbulkan bau menyengat pada air.

Untuk mengetahui konsentrasi klor aktif pada saluran distribusi PDAM (konsumen) selama proses distribusi dari reservoir ke konsumen maka perlu dilakukan suatu penelitian 
sehingga dapat memberikan gambaran dan perkiraan besarnya konsentrasi klor yang harus digunakan di reservoir sehingga air yang didistribusikan ke konsumen (masyarakat) benarbenar telah memenuhi standar kesehatan sesuai dengan yang tercantum dalam PERMENKES No 907 / MENKES / SK / VII / 2002. Oleh karena itu penelitian ini menarik dan penting untuk dilakukan dan diharapkan akan dapat memberikan manfaat bagi PDAM tentang proses disinfeksi menggunakan gas klor serta dapat menjadi bahan pertimbangan bagi masyarakat (konsumen) dalam mengkonsumsi atau memanfaatkan air PDAM untuk keperluan sehari-hari. Konsentrasi klor aktif yang akan diteliti adalah dari reservoir Tegal Sari ke Konsumen di Kecamatan Buleleng yaitu di kota Singaraja bagian barat yang mencakup Desa Bakti seraga, Banyuasri, Tukadmungga, Anturan, Kalibukbuk, dan Lovina. Penelitian dilakukan di daerah ini karena pada daerah ini jumlah pengguna air minum PDAM cukup banyak dan juga di daerah ini belum pernah dilakukan penelitian tentang konsentrasi klor aktif.

\section{Metode}

Penelitian ini merupakan penelitian deskriptif, yang bertujuan untuk memberi gambaran/deskripsi mengenai kualitas air minum PDAM Kabuparen Buleleng ditinjau dari parameter konsentrasi klor aktif. Penelitian ini dilaksanakan di saluran distribusi air PDAM Kabupaten Buleleng yang mencakup wilayah kota Singaraja bagian baiat yaitu desa Baktiseraga, Tukadmungga, Kalibukbuk dan kawasan wisata Lovina. Penelitian ini dilaksanakan pada tanggal 17 -19 Agustus 2005.Subyek penelitian ini adalah air minum PDAM Kabupaten Buleleng Sedangkan obyek penelitian ini adalah konsentrasi klor aktif dalam air minum PDAM Buleleng.

Penelitian ini dilakukan dalam dua tahap yaitu tahap persiapan dan tahap pengambilan data. Tahap persiapan dalam penelitian ini meliputi persiapan instrumentasi dan bahan yang akan dibawa ke lapangan dan digunakan dalam pengambilan data, penenentuan lokasi sampling serta pengajuan permohonan izin melakukan penelitian

Adapun alat dan bahan yang digunakan dalam penelitian ini antara lain sebagai berikut: 1) Komparator Taillor lengkap dengan cfeA/standar warna, 2) Kuvet komparator, 3) Termometer, 4) Pipet tetes, 5) Tablet DPD.

Pengambilan sampel dan pengukuran konsentrasi klor aktif dilakukan di outlet reservoir Tegal Sari dan kran konsumen, pada jarak distribusi $3 \mathrm{~km}, 6 \mathrm{~km}, 9 \mathrm{~km}$, dan $13 \mathrm{~km}$. Jumlah konsumen yang ada dari satu sambungan pipa induk ( $6 \mathrm{dim}$ ) dengan debit $175 \mathrm{lt} / \mathrm{dt}$ sebanyak 105 konsumen. Sampel penelitian diambil sebanyak 15 konsumen.Pengukuran konsentrasi klor aktif dilakukan dengan metode kolorimetri.

Dari penelitian ini akan diperoleh data mengenai konsentrasi klor aktif pada outlet reservoir Tegal Sari (konsentrasi klor aktif awal) dan konsentrasi klor aktif pada jaringan distribusi ( konsumen) pada jarak $3 \mathrm{~km}, 6 \mathrm{~km}, 9 \mathrm{~km}$, dan $13 \mathrm{~km}$ yang diukur pada pagi ( 07.00 WITA), siang (12.00 WITA), dan sore hari (18.00 WITA). Data konsentrasi klor aktif yang sudah diperoleh ini kemudian dirata-ratakan sehingga diperoleh rata-rata konsentrasi klor aktif pada pagi, siang, dan sore hari masing- masing pada jarak distribusi $3 \mathrm{~km}, 6 \mathrm{~km}, 9 \mathrm{~km}$, dan $13 \mathrm{~km}$. Kemudian rata-rata konsentrasi klor aktif tersebut dibandingkan dengan standar dari PERMENKES/No.907/MENKES/SK/VII/2002 untuk mengetahui kualitas air minum PDAM Buleleng pada saluran distribusi tersebut jika ditinjau dari parameter konsentrasi klor aktif. Konsentrasi klor aktif pada saluran distribusi ini juga dapat disajikan dalam bentuk grafik. Grafik ini akan menampilkan hubungan antara konsentrasi klor aktif pada pagi, siang, dan sore hari dengan jarak distribusi.

\section{Hasil dan Pembahasan}

Dari pengukuran konsentrasi klor aktif yang dilakukan pada saluran distribusi air minum PDAM Buleleng pada tanggal 17-19 Agustus 2005 maka diperoleh data sebagai berikut:

Tabel. 1. Data Rata-Rata Konsentrasi Klor Aktif pada Jaringan Distribusi Air Minum

\begin{tabular}{lccccc}
\hline \multirow{2}{*}{ Waktu } & $\mathbf{5}$ Jarak Distribusi \\
\cline { 2 - 6 } & $\mathbf{0}$ (Reservoir) & $\mathbf{3} \mathbf{~ k m}$ & $\mathbf{6 ~ k m}$ & $\mathbf{9} \mathbf{~ k m}$ & $\mathbf{1 3} \mathbf{~ k m}$ \\
\hline Pagi (07.00 WITA) & 0,4 & 0,38 & 0,28 & 0,20 & 0,13 \\
Siang (12.00 WITA) & 0,4 & 0,37 & 0,27 & 0,18 & 0,12 \\
Sore (18.00 WITA) & 0,4 & 0,36 & 0,26 & 0,17 & 0,11 \\
\hline
\end{tabular}


Data rata-rata konsentrasi klor aktif pada jaringan distribusi air PDAM Kabupaten Buleleng pada Tabel 1 diatas dapat disajikan dalam bentuk grafik seperti pada Gambar 1, di bawah ini

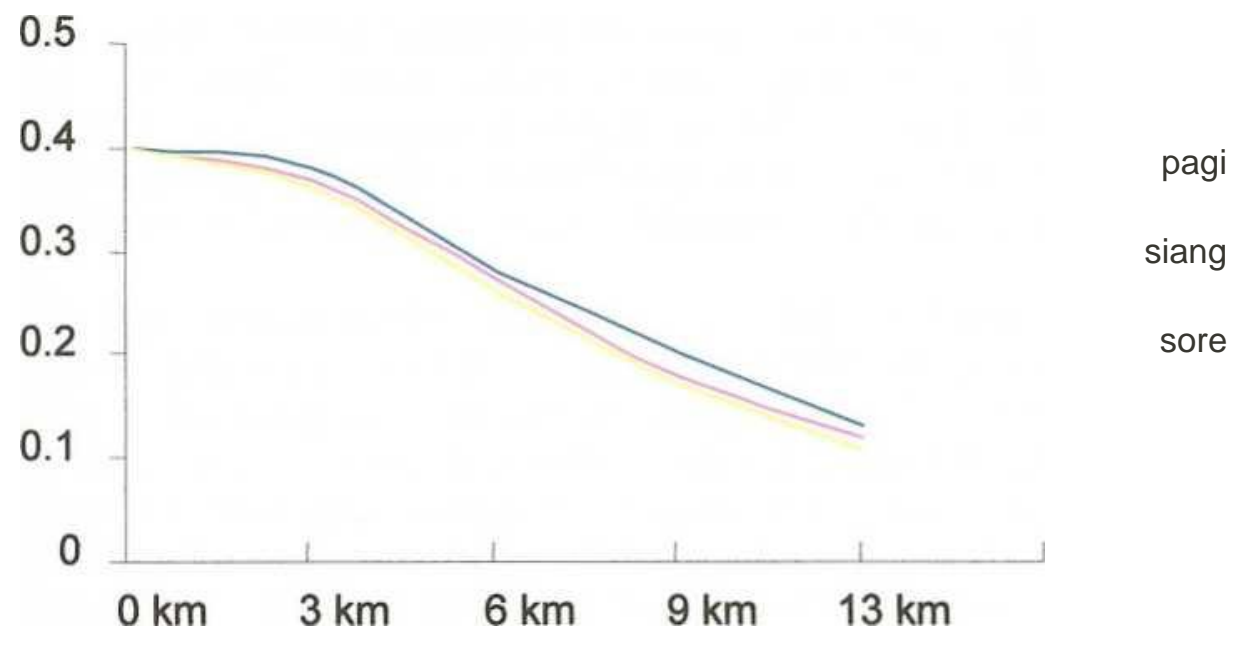

Jarak distribusi

Gambar 1. Grafik Hubungan Antara Konsentrasi Klor Aktif dengan Jarak Distribusi

Dari hasil analisis data maka dapat diperoleh penurunan konsentrasi klor aktif untuk masing-masing jarak distribusi (perhitungan disajikan dalam lampiran). Penurunan konsentrasi klor aktif yang terjadi pada jaringan distribusi dapat disajikan pada tabel 4.2 di bawah ini

Tabel 2. Penurunan Konsentrasi Klor Aktif pada Jaringan Distribusi

\begin{tabular}{lcccc}
\hline \multirow{2}{*}{ Waktu } & \multicolumn{4}{c}{ Jarak Distribusi } \\
\cline { 2 - 5 } & $\mathbf{3 ~} \mathbf{~ m}$ & $\mathbf{6 ~} \mathbf{~} \mathbf{m}$ & $\mathbf{9 ~} \mathbf{~ m}$ & $\mathbf{1 3} \mathbf{~ K m}$ \\
\hline Pagi ( 07.00 WITA) & $5 \%$ & $30 \%$ & $50 \%$ & $67,5 \%$ \\
Siang (12.00 WITA) & $7,5 \%$ & $32,5 \%$ & $55 \%$ & $70 \%$ \\
Sore(18.00 WITA) & $10 \%$ & $35 \%$ & $57,5 \%$ & $72,5 \%$ \\
\hline
\end{tabular}

Dari hasil penelitian yang disajikan pada Tabel 1 dapat diketahui bahwa konsentrasi klor aktif pada saluran distribusi air minum PDAM yang didistribusikan dari reservoir Tegal Sari berada pada rentangan $0,11-0,4 \mathrm{mg} / \mathrm{L}$. Konsentrasi klor aktif tertinggi yaitu sebesar $0,4 \mathrm{mg} / \mathrm{L}$ terdapat pada outlet reservoir Tegal Sari (jarak distribusi $0 \mathrm{~km}$ ) sedangkan konsentrasi klor aktif terendah yaitu sebesar $0,11 \mathrm{mg} / \mathrm{L}$ terdapat pada beberapa konsumen yang berada pada jarak distribusi 13 Km. Menurut PERMENKES No. 907/ MENKES/VII/2002 dalam jaringan distribusi air minum konsentrasi klor aktif maksimum yang diperbolehkan adalah $5 \mathrm{mg} / \mathrm{L}$. Dengan konsentrasi klor aktif 0,11-0,4 mg/L menunjukan bahwa air minum pada saluran distribusi air PDAM Kabupaten Buleleng memiliki kualitas yang baik ditinjau dari konsentrasi klor aktif.

Apabila konsentrasi klor aktif yang ada pada jaringan distribusi air minum melebihi 5 $\mathrm{mg} / \mathrm{L}$ maka dapat juga berdampak buruk bagi kesehatan masyarakat. Konsentrasi klor aktif yang melebihi nilai ambang batas pada air minum akan dapat menimbulkan bau yang menyengat pada air sehingga akan dapat mengurangi nilai estetika dari air minum tersebut. Konsentrasi klor aktif yang melebihi ambang batas juga dapat menimbulkanm gangguan kesehatan bagi masyarakat karena klor bersifat racun dan dapat menimbulkan berbagai penyakit (Totok Sutrisno,2002). Walaupun kualitas air minum PDAM Kabupaten Buleleng masih baik apabila ditinjau dari konsentrasi klor aktif namun dalam pemanfaatanya untuk keperluan minum masyarakat perlu melakukan pemanasan terlebih dahulu. Pemanasan yang dilakukan akan dapat mengurangi atau bahkan menghilangkan sisa klor yang masih ada di dalam air tersebut sehingga dapat mengantisipasi efek negatif yang ditimbulkan oleh klor di dalam air. 
Dari hasil penelitian yang disajikan pada grafik 4.1 dan tabel 4.2 dapat diketahui bahwa konsentrasi klor aktif pada saluran disribusi air minum PDAM dari reservoir Tegal Sari mengalami penurunan hingga sampai ke konsumen. Penurunan konsentrasi klor aktif ini terjadi karena beberapa hal antara lain terjadinya absorpsi klor aktif tersebut oleh bakteri-bakteri patogen dan mikroorganisme lainnya yang ada di dalam air tersebut, terjadinya reaksi oksidasireduksi (redoks) antara klor dengan beberapa logam yang terdapat dalam air, serta faktor penguapan sepanjang saluran distribusi air. Klor dalam bentuk Ch yang diinjeksikan di reservoir setelah kontak dengan air akan mengalami reaksi sebagai berikut:

$$
\mathrm{Cl}_{2(\mathrm{~g})}+\mathrm{H}_{2} \mathrm{O}_{(1)} \quad \ldots \ldots \ldots \ldots \ldots \text {. } \mathrm{H}_{(\mathrm{aq})}^{+}+\mathrm{CF}_{(\mathrm{aq})}+\mathrm{HOC}_{(\mathrm{l})}
$$

Asam hipoklorit pecah sesuai reaksi berikut:

$$
\operatorname{HOCl}_{(1)} \lll{ }^{*} \mathrm{H}_{(\mathrm{aq})}^{+}+\mathrm{OCr}_{(\mathrm{aq})}
$$

Ion $\mathrm{Cl}$ ' tidak aktif sedangkan $\mathrm{Cl}$, $\mathrm{HOC} 1$ dan OC1' dianggap sebagai bahan yang aktif dan berfungsi sebagai disinfektan (G Alaert dan Sri Sumanteri, 1994). Asam hipoklorit (H0C1) yang tidak terpecah adalah zat pembasmi yang paling efisien bagi bakteri dan mikroorganisme. Asam hipoklorit (HOC1) jika terabsorpsi oleh bakteri pathogen yang ada dalam air akan dapat merusak struktur sel dari bakteri dan mikroorganisme patogen tersebut. Bagian dari sel bakteri dan mikroorganisme yang akan mengalami kerusakan terutama pada bagian dinding sel, selaput plasma, protoplasma, nukleoid dan DNA. Hal ini dapat terjadi karena HOC1 bersifat asam dan sel bakteri tersebut sebagian besar (sekitar $38 \%$ ) tersusun atas protein. Protein ini juga merupakan komponen terpenting dari struktur sel bakteri karena berperan dalam kekakuan struktur, permeabilitas sel, mengatur kadar metabolit sel, menyebabkan gerakan sel, dan pembentukan DNA (Bruce Albert, 1994). Asam hipoklorit (HOC1) akan dapat memutuskan ikatan-ikatan peptida dari protein penyusun sel tersebut sehingga sel bakteri akan mengalami lisis karena protein sebagai komponen utamanya telah rusak. Dengan lisisnya sel, maka bakteri tersebut juga akan mengalami lisis dan menjadi inaktif. Dengan adanya proses disinfeksi terhadap bakteri-bakteri patogen ini maka konsentrasi klor aktif akan cenderung mengalami penurunan dari konsentrasi maksimum pada reservoir sampai pada konsentrasi minimum pada titik terjauh (konsumen teijauh ) pada saluran pipa distribusi.

Penurunan konsentrsi klor aktif di sepanjang saluran distribusi juga dapat terjadi karena klor merupakan oksidator kuat. Klor yang memiliki potensial reduksi standar sebesar 1,385 Volt jika diinjeksikan ke dalam air akan mengalami reaksi reduksi dan membentuk ion $\mathrm{Cf}$ dengan mengoksidasi beberapa logam yang memiliki potensial reduksi standar lebih kecil seperti $\mathrm{Fe}^{2+}(-$ 0,44 Volt), $\mathrm{Mn}^{+}\left(-1,18\right.$ Volt), $\mathrm{Pb}^{2+}\left(-0,13\right.$ Volt), $\mathrm{Zn}^{2+}\left(-0,76\right.$ Volt), $\mathrm{Sn}^{2+}\left(-0,14\right.$ Volt), $\mathrm{Mg}^{2+}(-2,37$ Volt) dan $\left.A\right|^{3+}(-1,66$ Volt) (Keenan, 1995). Sesuai dengan hasil pemeriksaan parameter kimia terbatas terhadap sumber mata air mumbul (hasil pemeriksaan terlampir) diketahui ternyata sumber mata air ini mengandung beberapa logam seperti besi $\left(\mathrm{Fe}^{2+}\right)$ sebanyak $0,3 \mathrm{mg} / \mathrm{L}$, mangan $\left(\mathrm{Mn}^{2+}\right)$ sebanyak $0,1 \mathrm{mg} / \mathrm{L}$, dan seng $\left(\mathrm{Zn}^{2+}\right)$ sebanyak $0,03 \mathrm{mg} / \mathrm{L}$. Hal ini memungkinkan bagi gas klor (Ch) sepanjang saluran distribusi air ini untuk mengalami reaksi reduksi dan mengoksidasi logam-logam yang ada tersebut. Dengan demikian konsentrasi klor aktif dalam saluran distribusi air ini juga akan cenderung semakin kecil.

Faktor lain yang dapat mempengaruhi penurunan konsentrasi klor aktif adalah faktor suhu (temperatur). Klor merupakan gas yang mudah menguap sehingga dengan terjadinya kenaikan temperatur akan dapat mempercepat penguapan gas klor sehingga akan menyebabkan semakin banyak konsentrasi klor yang hilang karena penguapan. Dengan demikian konsentrasi klor aktif yang $\mathrm{m}$,asih tersisa disepanjang saluran distribusi air ini juga akan semakin kecil. Selain itu suhu (temperatur) juga akan mempengaruhi kecepatan reaksi redoks gas klor dengan beberapa logam di dalam air. Kenaikan suhu akan menyebabkan reaksi redoks menjadi semakin cepat. Hal ini akan menyebabkan konsentrasi klor aktif semakin kecil di sepanjang saluran distribusi air tersebut.

Berdasarkan hasil penelitian yang disajikan pada grafik 4.1 dan tabel 4.2 dapat diketahui bahwa semakin jauh jarak pendistribusiannya maka persentase penurunan klor aktif semakin besar. Hal ini terjadi karena dalam peijalanannya disepanjang saluran distribusi tersebut klor juga terus mengalami reaksi reduksi dan mengoksidasi beberapa logam yang ada di dalam air. Dengan demikian dalam peijalanannya di sepanjang saluran distribusi konsentrasi klor aktif yang bereaksi akan semakin banyak sehingga konsentrasi klor aktif akan terus mengalami penurunan. Selain itu penurunan konsentrasi klor aktif yang semakin besar di 
sepanjang saluran distribusi ini juga dipengaruhi oleh reaksi antara klor aktif tersebut dengan beberapa jenis bakteri karat besi yang ada disepanjang saluran distribusi tersebut. Beberapa jenis bakteri karat yang umum ada di dalam air antara lain Sporovibrio desulfuricans, Flavobacterium, Pseudomonas, dan clostfridia. Bakteri ini dapat hidup disepanjang saluran pipa air PDAM ini karena bakteri-bakteri tersebut hidup dengan baik pada air dengan kadar besi antara 0,1-0,3 mg/L (Bruce Albert, 1994) dan dari hasil pemeriksaan diketahui air minum PDAM Buleleng mengandung besi sebesar $0,3 \mathrm{mg} / \mathrm{L}$. Dengan keberadaan bakteri karat ini maka klor aktif yang terdapat dalam saluran distribusi ini akan bereaksi untuk meninaktifkan bakteri tersebut. Bakteri-bakteri tersebut akan menjadi inaktif jika diinjeksikan dengan klor antara 0,1$0,3 \mathrm{mg} / \mathrm{L}$ (Kiyotoka Morri, 1993). Dengan semakin banyaknya klor aktif yang bereaksi dengan bakteri-bakteri tersebut dalam perjalanannya di sepanjang saluran distribusi, maka konsentrasi klor aktif akan semakin kecil apabila jarak yang dilalui oleh air tersebut semakin jauh. Akibatnya penurunan konsentrasi klor aktif akan meningkat dengan semakin jauhnya jarak distribusi.

Dari Tabel 2 dan Gambar 1 diketahui bahwa penurunan konsentrasi klor aktif yang teijadi pada siang hari lebih besar jika dibandingkan dengan pada pagi hari. Hal ini teijadi karena suhu pada siang hari $\left(31^{\circ} \mathrm{C}\right)$ lebih tinggi jika dibandingkan dengan suhu pada pagi hari $\left(29^{\circ} \mathrm{C}\right)$. Suhu yang semakin tinggi akan mempercepat penguapan klor akti t' tersebut sehingga dengan suhu yang lebih tinggi konsentrasi klor aktif yang menguap akan semakin banyak. Akibatnya konsentrasi klor aktif yang tersisa akan semakin kecil pada suhu yang lebih tinggi. $\mathrm{Hal}$ ini menyebabkan penurunan konsentrasi klor aktif yang lebih besar bila dibandingkan dengan penurunan konsentrasi klor aktif pada pagi hari. Selain itu pada suhu yang lebih tinggi reaksi oksidasi beberapa logam oleh klor akan menjadi semakin cepat sehingga semakin banyak klor yang bereaksi dengan logam akibatnya konsentrasi klor aktif yang ada dalam air akan semakin kecil. Hal ini menyebabkan penurunan konsentrasi klor aktif yang lebih besar jika dibandingkan dengan penurunan konsentrasi klor aktif pada pagi hari. Penurunan konsentrasi klor aktif terbesar justru terjadi pada sore hari walaupun suhu pada sore hari $\left(30^{\circ} \mathrm{C}\right)$ lebih rendah jika dibandingkan dengan suhu pada siang hari. Hal ini kemungkinan terjadi karena setelah pengukuran konsentrasi klor pada siang hari ( pukul 12.00 WITA) suhu masih mungkin untuk terus meningkat atau konstan sehingga mengakibatkan reaksi redoks antara klor dengan beberapa logam terus berlangsung secara maksimal sehingga konsentrasi klor aktif yang bereaksi juga dalam jumlah yang maksimal akibatnya konsentrasi klor aktif yang tersisa juga akan semakin kecil. Selain itu dengan adanya kemungkinan peningkatan suhu atau konstanya suhu setelah jam 12.00 WITA maka penguapan klor juga mungkin dapat terjadi secara maksimal sehingga konsentrasi klor yang menguap pada saat itu juga maksimal, akibatnya konsentrasi klor aktif yang ada dalam air akan semakin kecil. Hal ini kemungkinan terjadi sampai sore hari yaitu ketika dilakukan pengambilan sampel ( pukul 18.00 WITA) dimana pada saat itu suhu mulai turun menjadi $30^{\circ} \mathrm{C}$, namun hasil yang terukur pada saat itu kemungkinan adalah hasil reaksi yang terjadi secara maksimal dari siang sampai sore hari tersebut sehingga konsentrasi klor aktif yang terukur pada sore hari paling kecil. Hal ini menyebabkan penurunan konsentrasi klor aktif pada sore hari menjadi paling besar jika dibandingkan dengan penurunan yang terjadi pada pagi dan siang hari.

\section{Simpulan dan Saran}

Dari penelitian dapat ditarik kesimpulan diantaranya yaitu: 1) Air minum PDAM pada saluran distribusi dari reservoir Tegal Sari memiliki kualitas yang baik bila ditinjau dari konsentrasi klor aktif. Konsentrasi klor aktif yang ada pada saluran distribusi tersebut memenuhi syarat kualitas air minum dari Departemen Kesehatan (Depkes) dalam PERMENKES No.907/MENKES/SK/VII/2002. 2) Konsentrasi klor aktif pada saluran distribusi air PDAM cenderung mengalami penurunan seiring dengan bertambahnya jarak distribusi. Konsentrasi klor aktif pada sore hari lebih kecil dari konsentrasi klor aktif pada pagi dan siang hari.

Saran yang dapat penullis berikan yaitu: 1) Mengingat pentingnya pemeriksaan terhadap konsentrasi klor aktif pada saluran distribusi air minum maka diharapkan kepada pihak PDAM Kabupaten Buleleng untuk melakukan pemeriksaan dan pengawasan yang kontinyu di semua saluran distribusi dan sumber air minum PDAM Kabupaten Buleleng, 2) Masyarakat dalam memanfaatkan air PDAM Buleleng diharapkan memperhatikan konsentrasi klor aktif pada saluran distribusi baik pada pagi, siang dan sore hari, 3) Perlu dilakukan penelitian sejenis ini lagi dengan mengambil tempat di saluran distribusi yang bersumber dari sumber air dan Reservoir lain yang dimiliki oleh PDAM Kabupaten Buleleng. 


\section{Daftar Pustaka}

Ahmad Hiskia.2001. Kimia Unsur dan Radiokimia. Bandung : Citra Aditya Bakti.

Alaert, G dan Sri Sumestri santika. 1984. Metode Penelitian Air. Surabaya : Usaha Nasional.

Anonim, PERMENKES No.907/MENKES/SK/VII/2002 Departemen Kesehatan : Jakarta.

Anonim, Standar Operasional Prosedur (SOP) Laboratorium PDAM Buleleng.

Anonim, Keputusan Bupati Buleleng No.397 tahun 1993 tanggal 2 Agustus 1993 tentang Struktur Organisasi dan Tata Kerja PDAM Kab. Buleleng.

Bruce Albert, et.al. 1994. Biologi Molekuler Sel. Jakarta: Gramedia Pustaka.

Keenan, et. Al. 1995. Kimia Untuk Universitas.Jakarta: PT Erlangga

Kiyotoka Morri, et.al. 1993. Manual on Hydrology. Diterjemahkan oleh Suyono Sosrodarsono dan Kensuka Takeda. Jakarta : Paradnya Paramitha.

Sri Harto BR. 1993. Analisis hidrologi. Jakarta : Gramedia Pustaka Utama.

Sudiana,Manipan Siregar dan Lanang Wiratma. 2002 Bahan Ajar Kimia Analisis Air. Singaraja : Jurdik Kimia IKIP N Singaraja.

Winaja, I Wayan. 1986. Perubahan Konsentrasi Klor Aktif pada Saluran Distribusi Air PDAM Buleleng. Skripsi.Tidak Diterbitkan. 